\title{
Hongia gen. nov., a new genus of the order Actinomycetales
}

\author{
Soon Dong Lee, Sa-Ouk Kang and Yung Chil Hah
}

Department of

Microbiology, College of

Natural Sciences and

Research Center for

Molecular Microbiology, Seoul National University, Seoul 151-742, Republic of Korea

\author{
Author for correspondence: Yung Chil Hah. Tel: +822880 6700. Fax: +8228884911 \\ e-mail: hahyungc@snu.ac.kr
}

Keywords: Hongia gen. nov., actinomycetes, Propionibacterineae, phylogeny

\section{INTRODUCTION}

Phylogenetic analysis based on 16S rDNA (rDNA) sequence data is currently one of the most effective methods for the delineation of bacteria. The suborder Propionibacterineae Rainey et al. (Stackebrandt et al., 1997) of the order Actinomycetales (Buchanan) Stackebrandt et al. (Stackebrandt et al., 1997) encompasses the type family Propionibacteriaceae (Delwiche) Rainey et al. (Stackebrandt et al., 1997) and the family Nocardioidaceae (Nesterenko et al.) Rainey et al. (Stackebrandt et al., 1997), on the basis of 16S rDNA studies. The family Nocardioidaceae contains the genera Aeromicrobium (Miller et al., 1991; Tamura \& Yokota, 1994) and Nocardioides (Collins et al., 1989, 1994; O'Donnell et al., 1982a; Prauser, 1976, 1984). The family Propionibacteriaceae contains the genera

Abbreviations: LL-DAP, LL-diaminopimelic acid; ISP, International Streptomyces Project.

The EMBL accession number for the $16 \mathrm{~S}$ rDNA sequence of strain LM $161^{\top}$ is Y09159.
Luteococcus (Tamura et al., 1994), Microlunatus (Nakamura et al., 1995), Propioniferax (Yokota et al., 1994) and Propionibacterium (Cummins \& Johnson, 1986). The recently described genus Friedmanniella (Schumann et al., 1997) was shown to be a new member of the family Propionibacteriaceae. All of the members, except for the genus Propionibacterium (Cummins \& Johnson, 1986), possess cell wall peptidoglycan based on LL-diaminopimelic acid (LL-DAP) as the diagnostic diamino acid and exhibit a range of cell morphology from coccus- or rod-shaped forms to nocardioforms. Recently, the phylogenetic relationship between members of the family Nocardioidaceae and related taxa was re-evaluated on the basis of $16 \mathrm{~S}$ rDNA sequence comparisons (Yoon et al., 1998).

In addition, the following LL-DAP-containing actinomycete genera, which belong to other phylogenetic lineages (Stackebrandt et al., 1997), have been described: Streptomyces (Williams et al., 1989), Sporichthya (Rainey et al., 1993), Kineosporia (Itoh et al., 1989), Intrasporangium (Kalakoutskii et al., 1967), Terrabacter (Collins et al., 1989) and Terracoccus 
(Prauser et al., 1997). The members of the suborder Propionibacterineae are readily differentiated from each other and from the other LL-DAP-containing genera mentioned above by a combination of morphological, physiological and chemotaxonomic properties (Prauser et al., 1997; Schumann et al., 1997).

During the taxonomic study of soil actinomycetes from natural environments, strain LM $161^{\mathrm{T}}(\mathrm{T}=$ type strain) was isolated from a gold-mine cave in Kongju, Republic of Korea. Strain LM $161^{\mathrm{T}}$ contained LLDAP as the diagnostic diamino acid in the peptidoglycan, and the substrate- and aerial mycelia showed a tendency to fragment. In this work, we have determined the taxonomic and phylogenetic position of the isolate by examining its morphological, physiological and chemotaxonomic properties and by analysing its $16 \mathrm{~S}$ rDNA. Our results indicate that the isolate should be placed in a new species of a novel genus, for which the name Hongia koreensis is proposed. Strain LM $161^{\mathrm{T}}$ has been deposited in the Culture Collection Centre of the Institute of Microbiology, Seoul National University (IMSNU) as strain IMSNU $50530^{\mathrm{T}}$.

\section{METHODS}

Micro-organisms and culture conditions. Strain LM $161^{\mathrm{T}}$ was isolated, using the dilution plating method, from soil collected at a gold-mine cave in Kongju, Republic of Korea. The soil suspensions were pretreated at $30^{\circ} \mathrm{C}$ for $20 \mathrm{~min}$ before plating (Lee, 1996). The medium used for selective isolation was a tap-water agar ( $\mathrm{pH} 7 \cdot 0)$ supplemented with $50 \mathrm{~g}$ cycloheximide $\mathrm{ml}^{-1}$ and $50 \mathrm{~g}$ nystatin $\mathrm{ml}^{-1}$. After the purity had been checked, the organism was subcultured on yeast extract/malt extract agar [medium 2 of the International Streptomyces Project (ISP)] (Shirling \& Gottlieb, 1966) at $28^{\circ} \mathrm{C}$. The following reference strains were used to compare chemotaxonomic properties: Aeromicrobium erythreum DSM $8599^{\mathrm{T}}$, Aeromicrobium fastidiosum IFO $14987^{\mathrm{T}}$, Nocardioides albus IFO $13917^{\mathrm{T}}$, Nocardioides jensenii KCTC $9134^{\mathrm{T}}$, Nocardioides luteus IFO 14491 ${ }^{\mathrm{T}}$, Nocardioides simplex IFO $12069^{\mathrm{T}}$, Luteococcus japonicus IFO $12422^{\mathrm{T}}$, Microlunatus phosphovorus JCM 9379 ${ }^{\mathrm{T}}$, Propioniferax innocua DSM $8251^{\mathrm{T}}$ and Kineosporia aurantiaca IFO $13890^{\mathrm{T}}$.

Morphological and cultural characteristics. Growth and morphology were examined by using the ISP media described by Shirling \& Gottlieb (1966) and the media described by Waksman (1961). The formation of melanin was investigated on peptone/yeast extract/iron agar (ISP medium 6) and tyrosine agar (ISP medium 7). For scanning electron microscopy, cultures grown at $28{ }^{\circ} \mathrm{C}$ for $14 \mathrm{~d}$ on oatmeal agar (ISP medium 3) and inorganic salts/starch agar (ISP medium 4) were prepared by cutting agar blocks from the growth medium. The agar blocks were fixed with $1 \%(\mathrm{w} / \mathrm{v})$ osmium tetroxide, were dehydrated through a graded ethanol series and the ethanol was replaced with isoamyl acetate. After critical-point drying, the samples were sputter-coated with gold under a vacuum and observed under a Stereoscan model 260 scanning electron microscope.

Physiological characteristics. All physiological tests were performed at $28^{\circ} \mathrm{C}$ (unless otherwise indicated). Oxidase activity was checked by examining the oxidation of $1 \%$ $(\mathrm{w} / \mathrm{v})$ tetramethyl-p-phenylenediamine on paper discs.
Catalase activity was determined by the production of bubbles after the addition of a drop of $3 \%(\mathrm{v} / \mathrm{v})$ hydrogen peroxide solution on to a slide. Growth was tested over a range of temperatures $\left(10-45^{\circ} \mathrm{C}\right)$ and $\mathrm{pH}$ values $(5-10)$. Nitrate reduction, urease activity, hydrogen sulfide production, decomposition of hippurate and hydrolysis of arbutin, casein, aesculin, gelatin and starch were tested as described by Mac Faddin (1980). Hydrolysis of the DNA was determined using Bacto DNase test agar (Difco). Pectinolytic activity was examined according to the method of Hankin et al. (1971). Acid production from carbohydrates was determined by means of a colour change from green to yellow in Bacto OF basal medium (Difco). The utilization of organic acids as carbon sources and the decomposition of adenine, hypoxanthine, DL-tyrosine and xanthine were examined using previously described methods (Gordon et al., 1974). The utilization of carbohydrates as the sole carbon source was studied according to the method of Pridham \& Gottlieb (1948). NaCl-tolerance studies were performed on nutrient agar containing $\mathrm{NaCl}$ at final concentrations of $3,5,7$ and $10 \%(\mathrm{w} / \mathrm{v})$. Susceptibility to antibiotics and chemical inhibitors was determined as described previously (Williams et al., 1983). To determine sensitivity to lysozyme, a $0 \cdot 1 \%$ solution of lysozyme was sterilized by membrane filtration and added to nutrient agar at a final concentration of $0 \cdot 01 \%$. Antimicrobial activity was tested for nine target organisms by using the overlay technique of Williams et al. (1983).

Cell wall analysis. Purified cell wall peptidoglycan was prepared according to the method of Yamada \& Komagata (1972) and its amino acid composition was analysed by twodimensional, ascending TLC on cellulose plates by using the solvent systems described previously (Schleifer \& Kandler, 1972). The molar ratio of amino acids was determined by GC of $N$-heptafluorobutyryl amino acid isobutyl esters (O'Donnell et al., 1982b). The isomers of diaminopimelic acid were determined according to the method of Staneck \& Roberts (1974). Cell wall sugars as alditol acetates were determined by GC (Saddler et al., 1991). GC analyses were performed with a Hewlett Packard model HP5890A gas chromatograph equipped with a flame-ionization detector and integrator. The acyl type of the cell wall was determined using the colorimetric method of Uchida \& Aida (1984).

Lipid analysis. Cellular fatty acid methyl esters were prepared from cells grown on yeast extract/glucose broth at $30{ }^{\circ} \mathrm{C}$ for $3 \mathrm{~d}$ by alkaline methanolysis (Minnikin, 1988) and were analysed with a Hewlett Packard model 5890A gas chromatograph equipped with a SPB-1 fused silica capillary column $(0.25 \mathrm{~mm} \times 30 \mathrm{~m}$; Supelco $)$. The column temperature was programmed according to the manufacturer's instructions. The fatty acid methyl esters were identified by comparison with the Bacterial Acid Methyl Ester CP MIX (catalogue no. 1114; Matreya). Phospholipids and menaquinones were extracted using the integrated method of Minnikin et al. (1984). The resultant phospholipids were separated by two-dimensional TLC (Minnikin et al., 1977) and identified by comparison with standards and by spraying with specific reagents (Collins et al., 1982). The purified menaquinones were analysed using HPLC as described by Kroppenstedt (1985). Mycolic acids were determined using TLC (Minnikin et al., 1980).

DNA base composition. Genomic DNA was extracted according to the method described by Hopwood et al. (1985). The $\mathrm{G}+\mathrm{C}$ content of the DNA was determined by using the thermal denaturation method (Marmur \& Doty, 1962). 
Molecular cloning and sequencing of the 16S rRNA gene (rDNA). The amplification of $16 \mathrm{~S}$ rDNA was carried out by using a DNA thermal cycler (Perkin-Elmer) in combination with the following two universal primers: $27 \mathrm{f}\left(5^{\prime}-\mathrm{AG}-\right.$ AGTTTGATCMTGGCTCAG OH-3'; positions 8-27 (Escherichia coli numbering) and 1525r (5'-AAGGAGGTGWTCCARCC OH-3'; positions 1541-1525) (Brosius et al., 1978). The temperature programme consisted of 30 cycles of denaturation at $94{ }^{\circ} \mathrm{C}$ for $1 \mathrm{~min}$, primer annealing at $55^{\circ} \mathrm{C}$ for $1 \mathrm{~min}$ and extension at $72^{\circ} \mathrm{C}$ for $3 \mathrm{~min}$. For the last cycle, the reaction mixture was further incubated at $72{ }^{\circ} \mathrm{C}$ for $10 \mathrm{~min}$. The PCR product was purified with a GeneClean kit (Bio 101) and ligated into vector pGEM-T (Promega) according to the manufacturer's instructions. The ligation product was transformed into competent $E$. coli DH $5 \alpha$ cells. The DNA sequence was determined by using a model ALFexpress DNA sequencer (Pharmacia Biotech) and the Cy5 AutoRead Sequencing kit (Pharmacia).

Phylogenetic analysis. An almost complete 16S rDNA sequence was obtained from partial sequences derived from sequencing reactions by using a DNASIS program. The $16 \mathrm{~S}$ rDNA sequence determined and previously published sequences of reference actinomycetes were aligned by using the program CLUSTAL W (Thompson et al., 1994). Evolutionary distances were calculated by the method of Jukes \& Cantor (1969). A phylogenetic tree was reconstructed by the tree-making algorithms contained in the PHYLIP package (Felsenstein, 1993). The topology of the tree was evaluated by performing bootstrap analysis (Felsenstein, 1985) of the neighbour-joining data, using 1000 resamplings.

Nucleotide sequence accession numbers. The reference sequences, which were used in the phylogenetic analysis, were sequences available from the DDBJ, EMBL and GenBank nucleotide sequence databases under the following accession numbers: Actinoplanes philippinensis DSM 43019 ${ }^{\mathrm{T}}$, X93187; Aeromicrobium erythreum NRRL B-3381 ${ }^{\mathrm{T}}$, M37200; Aeromicrobium fastidiosum NCIMB $12713^{\mathrm{T}}$, X76862; Apotobium minutum, ATCC 33267 ${ }^{\mathrm{T}}$, M59059; Friedmanniella antarctica, DSM $11053^{\mathrm{T}}$, Z78206; Intrasporangium calvum, IFO 12989 ${ }^{\mathrm{T}}$, D85486; Kineosporia aurantiaca, ATCC $28727^{\mathrm{T}}$, X87110; Luteococcus japonicus DSM 10546 ${ }^{\mathrm{T}}$, Z78208; Microbacterium lacticum, DSM $20427^{\mathrm{T}}$, X77441; Microlunatus phosphovorus, DSM 10555 ${ }^{\mathrm{T}}$, Z78207; Nocardia asteroides, DSM 43757 ${ }^{\mathrm{T}}$, X80606; Nocardioides albus DSM 43109 ${ }^{\mathrm{T}}$, X53211; Nocardioides jensenii DSM 20641 ${ }^{\mathrm{T}}$, X53214; Nocardioides simplex DSM 20130 ${ }^{\mathrm{T}}$, Z78212; Propionibacterium freudenreichii DSM $20271^{\mathrm{T}}$, X53217; Saccharothrix australiensis, ATCC $31947^{\mathrm{T}}$, X53193; Sporichthya polymorpha DSM 46113 ${ }^{\mathrm{T}}$, X72377; Streptomyces griseus subsp. griseus KCTC $9080^{\mathrm{T}}$, M76388; Streptosporangium roseum, DSM 43021 ${ }^{\mathrm{T}}$, X89947; Terracoccus luteus, DSM 44267 ${ }^{\mathrm{T}}$, Y11928; and Terrabacter tumescens DSM 20308 ${ }^{\mathrm{T}}$, X83812. The sequence of Propioniferax innocua was obtained from the study of Pitcher \& Collins (1991).

\section{RESULTS}

\section{Morphological and cultural characteristics}

A study of its cultural and morphological characteristics showed that strain LM $161^{\mathrm{T}}$ has morphological properties similar to features that are characteristic of nocardioform organisms. Strain LM $161^{\mathrm{T}}$ produced true mycelia with well-developed, irregularly branched hyphae. The aerial mycelium was white and

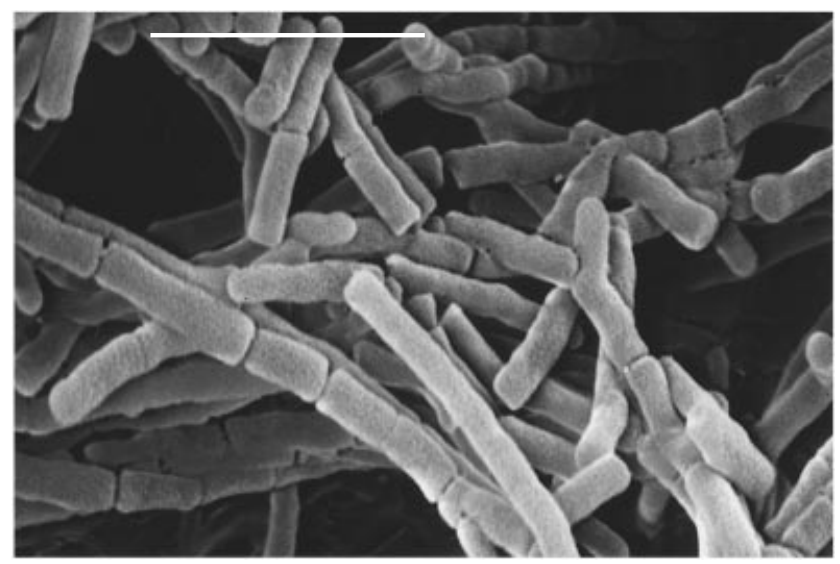

Fig. 1. Scanning electron micrograph of aerial mycelium of strain LM $161^{\top}$ grown on inorganic salts/starch agar (ISP medium 4) for $14 \mathrm{~d}$. Bar, $2 \mu \mathrm{m}$.
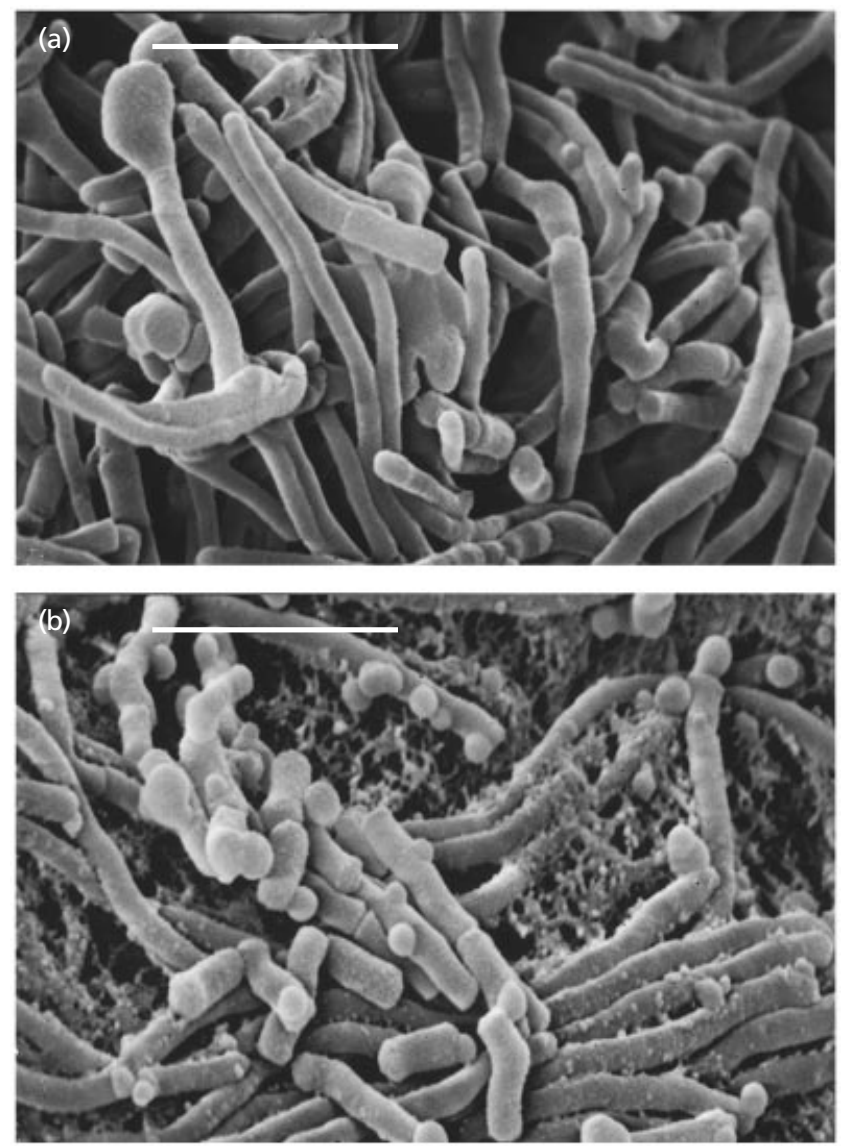

Fig. 2. Scanning electron micrograph of substrate mycelium of strain LM $161^{\top}$ grown on oatmeal agar (ISP medium 3) for $14 \mathrm{~d}$. (a) Hyphal swelling. (b) Budding. Bars, $2 \mu \mathrm{m}$.

fragmented into rod-shaped elements (Fig. 1). The substrate mycelium was creamy and also fragmented into short to elongated rod-shaped elements (Fig. 2). Hyphal swelling on the hyphal tips (Fig. 2a) and 
Table 1. Cellular fatty acid composition (\%) of strain $\mathrm{LM} 161^{\top}$ and the type strains of related taxa that belong to the suborder Propionibacterineae

Values less than $1 \%$ not shown.

\begin{tabular}{|c|c|c|c|c|c|c|c|c|c|c|c|c|c|c|c|c|c|}
\hline \multirow[t]{2}{*}{ Taxon } & \multicolumn{5}{|c|}{ Saturated } & \multicolumn{3}{|c|}{ Unsaturated } & \multicolumn{4}{|c|}{ Iso } & \multicolumn{2}{|c|}{ Anteiso } & \multicolumn{3}{|c|}{ 10-Methyl } \\
\hline & $\mathrm{C}_{14}$ & $\mathrm{C}_{15}$ & $\mathrm{C}_{16}$ & $\mathrm{C}_{17}$ & $\mathrm{C}_{18}$ & $\mathrm{C}_{15}$ & $\begin{array}{ll}C_{16} & C_{17}\end{array}$ & $\mathrm{C}_{18}$ & $\mathrm{C}_{14}$ & $\mathrm{C}_{15}$ & $\mathrm{C}_{16}$ & $\mathrm{C}_{17}$ & $\mathrm{C}_{15}$ & $\mathrm{C}_{17}$ & $\mathrm{C}_{16}$ & $\mathrm{C}_{17}$ & $\mathrm{C}_{18}$ \\
\hline Strain LM $161^{\mathrm{T}}$ & & $1 \cdot 9$ & $6 \cdot 6$ & $4 \cdot 0$ & $1 \cdot 7$ & & & & 5.9 & $12 \cdot 3$ & $24 \cdot 0$ & $5 \cdot 1$ & $24 \cdot 7$ & 4.9 & $5 \cdot 1$ & $4 \cdot 0$ & \\
\hline $\begin{array}{l}\text { Aeromicrobium erythreum } \\
\text { DSM } 8599^{\mathrm{T}}\end{array}$ & $1 \cdot 2$ & & $25 \cdot 2$ & $2 \cdot 0$ & $10 \cdot 9$ & & & $15 \cdot 1$ & & & $1 \cdot 0$ & & & & & & $34 \cdot 5$ \\
\hline $\begin{array}{l}\text { Aeromicrobium fastidiosum } \\
\text { IFO } 14987^{\mathrm{T}}\end{array}$ & & & $12 \cdot 9$ & $1 \cdot 8$ & $16 \cdot 1$ & & 1.5 & $48 \cdot 2$ & & & & & & $2 \cdot 0$ & & $8 \cdot 7$ & $9 \cdot 1$ \\
\hline $\begin{array}{l}\text { Nocardioides albus } \\
\text { IFO } 13917^{\mathrm{T}}\end{array}$ & & & $6 \cdot 4$ & $3 \cdot 7$ & $6 \cdot 7$ & $1 \cdot 0$ & $1 \cdot 8$ & $2 \cdot 4$ & 1.6 & $2 \cdot 2$ & $20 \cdot 3$ & $1 \cdot 7$ & $1 \cdot 0$ & $3 \cdot 8$ & $4 \cdot 8$ & $2 \cdot 7$ & $34 \cdot 0$ \\
\hline $\begin{array}{l}\text { Nocardioides luteus } \\
\text { IFO } 14491^{\mathrm{T}}\end{array}$ & & & $4 \cdot 2$ & $1 \cdot 8$ & $4 \cdot 0$ & & & $3 \cdot 6$ & & $1 \cdot 0$ & $50 \cdot 7$ & $1 \cdot 7$ & & $2 \cdot 4$ & $5 \cdot 1$ & & $13 \cdot 4$ \\
\hline $\begin{array}{l}\text { Nocardioides jensenii } \\
\text { KCTC } 9134^{\mathrm{T}}\end{array}$ & & & $10 \cdot 1$ & $3 \cdot 4$ & $10 \cdot 2$ & & $2 \cdot 6$ & $19 \cdot 5$ & & $2 \cdot 8$ & $17 \cdot 4$ & $3 \cdot 4$ & & $4 \cdot 8$ & $1 \cdot 8$ & $6 \cdot 1$ & $25 \cdot 9$ \\
\hline $\begin{array}{l}\text { Nocardioides simplex } \\
\text { IFO } 12069^{\mathrm{T}}\end{array}$ & & & $4 \cdot 9$ & $2 \cdot 8$ & $7 \cdot 3$ & & 1.9 & $49 \cdot 2$ & & 1.7 & $13 \cdot 4$ & $1 \cdot 8$ & & $6 \cdot 7$ & & & $2 \cdot 3$ \\
\hline $\begin{array}{l}\text { Luteococcus japonicus } \\
\text { IFO } 12422^{\mathrm{T}}\end{array}$ & & $2 \cdot 9$ & $4 \cdot 5$ & $2 \cdot 8$ & $4 \cdot 8$ & $7 \cdot 1$ & $30 \cdot 420 \cdot 6$ & $524 \cdot 4$ & & & & & & & & & \\
\hline $\begin{array}{l}\text { Microlunatus phosphovorus } \\
\text { JCM } 9379^{\mathrm{T}}\end{array}$ & & & $1 \cdot 2$ & & $1 \cdot 0$ & $3 \cdot 1$ & & & & $20 \cdot 0$ & 11.9 & $7 \cdot 5$ & $48 \cdot 9$ & $7 \cdot 3$ & & & \\
\hline $\begin{array}{l}\text { Propioniferax iпnосиа } \\
\text { DSM } 8251^{\mathrm{T}}\end{array}$ & & $4 \cdot 0$ & $3 \cdot 3$ & $2 \cdot 1$ & & & $3 \cdot 1$ & $4 \cdot 8$ & $3 \cdot 4$ & $15 \cdot 8$ & $7 \cdot 6$ & $2 \cdot 8$ & $36 \cdot 2$ & 11.6 & & & \\
\hline
\end{tabular}

budding on the hyphae (Fig. 2b) were observed on oatmeal agar. Strain LM $161^{\mathrm{T}}$ grew well on most solid media, as follows: yeast extract/malt extract agar (ISP medium 2), oatmeal agar (ISP medium 3), inorganic salts/starch agar (ISP medium 4), tyrosine agar (ISP medium 7), glucose/asparagine agar, Hickey-Tresner agar, nutrient agar and Bennett agar. Melanin pigments were not produced on any of the media tested.

\section{Physiological characteristics}

Strain LM $161^{\mathrm{T}}$ grew strictly aerobically. The temperature and $\mathrm{pH}$ ranges for growth were $10-37^{\circ} \mathrm{C}$ and $\mathrm{pH} 7-10$, respectively. Catalase, urease and $\mathrm{H}_{2} \mathrm{~S}$ were produced. Oxidase and nitrate reductase were not produced. Acid was produced from D-raffinose. No acid was produced from the following compounds: D-arabinose, L-arabinose, D-cellobiose, D-fructose, Dgalactose, D-glucose, inulin, D-lactose, maltose, Dmannose, D-melezitose, melibiose, methyl $\alpha$-D-glucoside, methyl $\alpha$-D-mannoside, L-rhamnose, L-ribose, salicin, sucrose, D-trehalose, D-xylose, adonitol, 2, 3butanediol, meso-erythritol, glycerol, meso-inositol, D-mannitol and 1,2-propanediol.

Gelatin, casein, starch, arbutin and aesculin were hydrolysed. Pectin and DNA were not hydrolysed. Xanthine, hypoxanthine, DL-tyrosine and sodium hippurate were decomposed but adenine was not decomposed. Strain LM $161^{\mathrm{T}}$ utilized D-arabinose, Larabinose, D-cellobiose, D-fructose, D-galactose, inu- lin, D-lactose, D-lyxose, D-mannose, D-melezitose, melibiose, methyl $\alpha$-D-glucoside, methyl $\alpha$-Dmannoside, D-raffinose, L-rhamnose, sucrose, D-trehalose, D-xylose, adonitol, D-mannitol, sodium acetate, trans-aconitate, sodium citrate, sodium fumarate, $\alpha$-ketoglutarate, sodium lactate, sodium malate, sodium malonate, sodium oxalate, sodium propionate, sodium pyruvate and sodium succinate as carbon sources.

Utilization of dextran, D-glucosamine, L-sorbose, dulcitol, D-sorbitol, D-xylitol, cis-aconitate, sodium benzoate, sodium formate, sodium maleate, sodium salicylate, sebacate, potassium sorbate or sodium tartarate was not observed. Strain LM $161^{\mathrm{T}}$ was resistant to lysozyme and grew in the presence of $0 \cdot 1 \%$ phenol, $0.01 \%$ potassium tellurite, $0.00005 \%$ crystal violet and $0.001 \%$ brilliant green, but not in the presence of $3 \%(\mathrm{w} / \mathrm{v})$ sodium chloride, $0.01 \%$ sodium azide, $0.3 \%$ phenylethanol or $0.01 \%$ thallous acetate.

Strain LM $161^{\mathrm{T}}$ was susceptible to $40 \mathrm{~g}$ cephaloridine $\mathrm{ml}^{-1}$ and $20 \mathrm{~g}$ neomycin $\mathrm{ml}^{-1}$, but resistant to $4 \mathrm{~g}$ tetracycline $\mathrm{ml}^{-1}, 4 \mathrm{~g}$ rifampin $\mathrm{ml}^{-1}, 20 \mathrm{~g}$ streptomycin $\mathrm{ml}^{-1}, 160 \mathrm{~g}$ oleandomycin $\mathrm{ml}^{-1}$ and $4 \mathrm{~g}$ vancomycin $\mathrm{ml}^{-1}$. Antimicrobial activity against any of the following organisms was not observed: Bacillus subtilis, Micrococcus luteus, Staphylococcus aureus, Streptomyces murinus, Escherichia coli, Enterobacter aerogenes, Saccharomyces cerevisiae, Candida albicans and Aspergillus niger. 


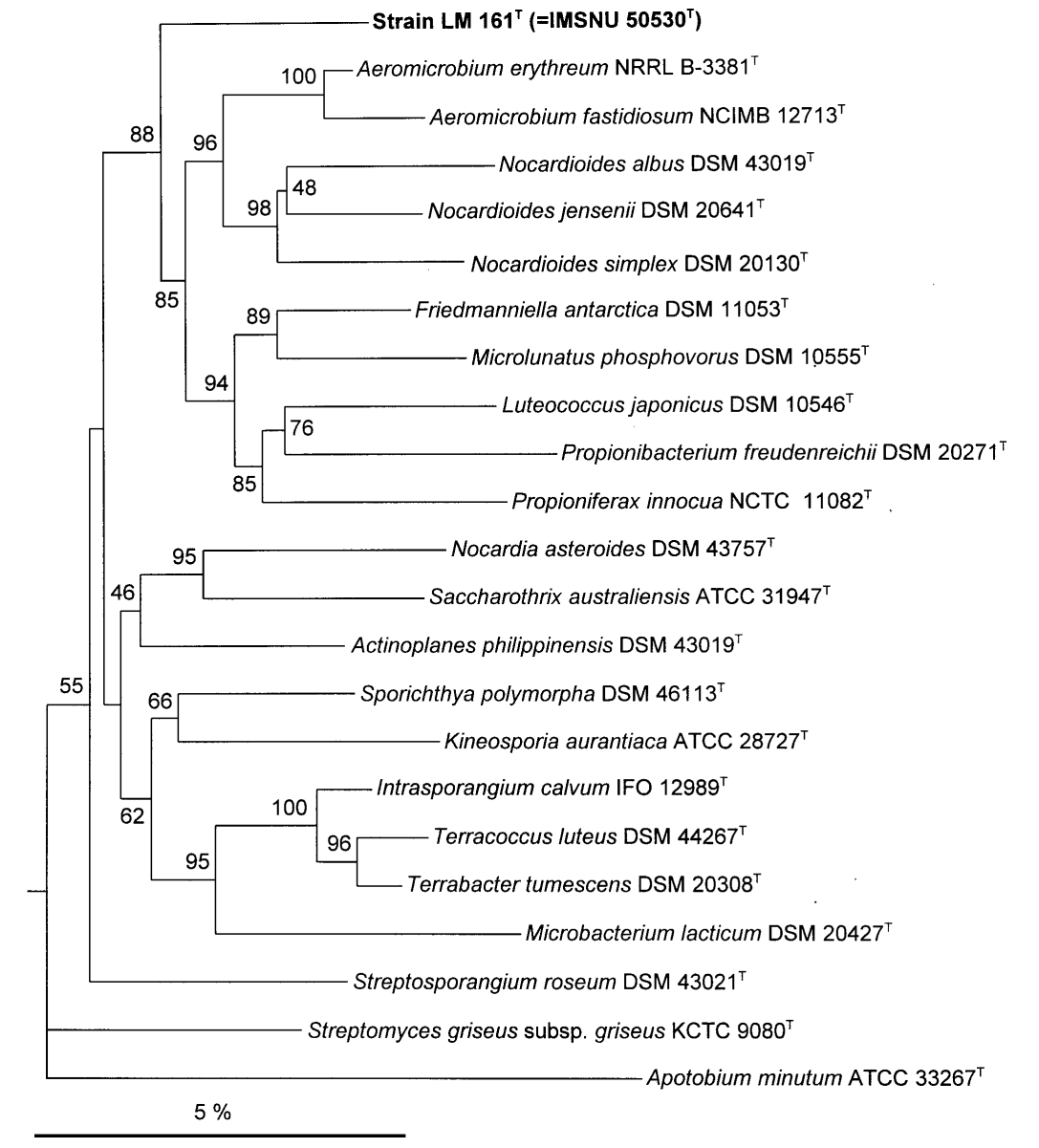

Fig. 3. Phylogenetic tree displaying the position of strain $L M 161^{\top}$ with regard to other related taxa. The neighbour-joining tree was based on 1256 nucleotide positions. The numbers at the branching points are bootstrap values expressed as percentages out of 1000 replications. Bar, 5 inferred nucleotide substitutions per 100 nucleotides.

\section{Chemotaxonomic characteristics}

The amino acids composing the peptidoglycan layer of strain LM $161^{\mathrm{T}}$ were LL-DAP, alanine, glycine and glutamic acid (molar ratio, approx. 1:2:1:1), indicating that the wall chemotype is type I, according to the classification of Lechevalier \& Lechevalier (1970), and that the peptidoglycan type is A $3 \gamma$, as described by Schleifer \& Kandler (1972). The acyl type was acetyl. Mannose, glucose, galactose and ribose were present as cell wall sugars. The major menaquinone was tetrahydrogenated menaquinone with nine isoprene units $\left[\mathrm{MK}-9\left(\mathrm{H}_{4}\right)\right]$. The polar lipid fraction contained phosphatidylcholine, diphosphatidylglycerol, phosphatidylglycerol and phosphatidylinositol, but phosphatidylethanolamine and gucosamine-containing phospholipids were absent; this corresponds to the phospholipid type III pattern as defined by Lechevalier et al. (1981). The predominant cellular fatty acids of strain LM $161^{\mathrm{T}}$ were 12-methyltetradecanoic acid (anteiso- $\mathrm{C}_{15: 0}$ acid) and 14-methyltetrapentadecanoic acid (iso-C $\mathrm{C}_{16: 0}$ acid). Straight-chain saturated and 10methyl-branched fatty acids were also present in small amounts, but unsaturated fatty acids and tuberculostearic acid (10-methyloctadecanoic acid) were not detected. The fatty acid profiles differ somewhat from those of the reference strains. The fatty acid profiles of the reference strains analysed in our study differed slightly from the profile reported previously (Miller et al., 1991; Nakamura et al., 1995; Schumann et al., 1997; Tamura et al., 1994), but the relative distribution of each chain length was similar. The cellular fatty acid compositions of strain LM $161^{\mathrm{T}}$ and the type strains of related taxa are shown in Table 1. Mycolic acids were absent. The $\mathrm{G}+\mathrm{C}$ content of the DNA of strain LM $161^{\mathrm{T}}$ was $71 \cdot 3 \mathrm{~mol} \%$.

\section{Phylogenetic analysis}

The almost complete 16S rDNA sequence of strain LM $161^{\mathrm{T}}$, consisting of 1510 nucleotides, was aligned and compared with the sequences of other actinomycete taxa. A total of 1256 nucleotides present in all strains between positions 39 and 1484 (E. coli numbering) were used in the analyses. A phylogenetic tree shown in Fig. 3 was reconstructed by the neighbour-joining method (Saitou \& Nei, 1987) from evolutionary distances (Jukes \& Cantor, 1969). The phylogenetic analysis based on the $16 \mathrm{~S}$ rDNA sequence comparisons showed that strain LM $161^{\mathrm{T}}$ represents a distinct line of descent within the radiation of the order Actinomycetales (Fig. 3). It formed a branching point at the root of members of two families Nocardioidaceae and Propionibacteriaceae belonging to the suborder Propionibacterineae Rainey et al. 
(Stackebrandt et al., 1997). The type and only species of the genus Kineosporia, K. aurantiaca ATCC $28727^{\mathrm{T}}$, which contains meso-DAP in the peptidoglycan in addition to LL-DAP and has a phylogenetic position that remains to be determined, was united with Sporichthya polymorpha (93.2\% sequence similarity) in our analysis.

\section{DISCUSSION}

The 16S rDNA sequence analysis placed strain LM $161^{\mathrm{T}}$ outside the clade corresponding to the suborder Propionibacterineae Rainey et al. of the order Actinomycetales (Buchanan) Stackebrandt et al. (1997) (Fig. 3 ). The relationship between strain LM $161^{\mathrm{T}}$ and the cluster comprising the members of the families Nocardioidaceae and Propionibacteriaceae is supported by a high bootstrap value of $88 \%$ and by the presence of all but one signature nucleotide previously defined for the suborder Propionibacterineae (Stackebrandt et al., 1997). In addition, the secondary structure of the 16S rDNA of strain LM $161^{\mathrm{T}}$ contains several nucleotide pairs differing from those of members of the families Nocardioidaceae and Propionibacteriaceae, represented by the $16 \mathrm{~S}$ rDNA nucleotide pairs at positions 370-391 (C-G), 371-390 $(\mathrm{G}-\mathrm{C}), \quad 378-385$ (A-U), 591-648 (C-A), 671-735 (G-C), 776 (A), 1001-1039 (G-C) and 1006-1023 (U-G). Pairwise comparison of the primary 16S rDNA structures shows that strain LM $161^{\mathrm{T}}$ exhibits mean nucleotide similarity values of $92 \cdot 7 \pm 1.4 \%$ with members of the family Nocardioidaceae and $90.9 \pm 1.9 \%$ with members of the family Propionibacteriaceae. The results of our phylogenetic analysis clearly indicated that strain LM $161^{\mathrm{T}}$ represents a distinct lineage in the order Actinomycetales.
In addition to $16 \mathrm{~S}$ rDNA sequence differences, strain LM $161^{\mathrm{T}}$ has chemotaxonomic properties that allow it to be clearly differentiated from its phylogenetic neighbours (Fig. 3) and other LL-DAP-containing actinomycete genera. The chemotaxonomic characteristics of LL-DAP-containing actinomycete genera were recently re-examined by Schumann et al. (1997) and the majority of the previously reported characteristics were also confirmed. Phospholipid patterns in combination with diamino acids are extremely useful in distinguishing strain LM $161^{\mathrm{T}}$ from the LL-DAPcontaining actinomycete genera and other taxa previously reported in the order Actinomycetales. To date, the phospholipid type III pattern (the diagnostic phospholipid is phosphatidylcholine) and the occurrence of LL-DAP have only been reported for the actinomycete Kineosporia aurantiaca (Itoh et al., 1989). All of the LL-DAP-containing actinomycete genera, with the exception of $K$. aurantiaca, have phospholipid type I or II patterns according to Lechevalier et al. (1981) in that phosphatidylcholine or gucosaminecontaining phospholipids were absent from their phospholipid compositions (Prauser et al., 1997; Schumann et al., 1997). The diagnostic phospholipid profiles (of the phospholipid type III pattern; Table 2) and the cellular fatty acid profiles of the isolate (Table 1) are clearly distinguishable from those of actinomycete genera with LL-DAP in their peptidoglycan (Collins et al., 1989; Miller et al., 1991; Nakamura et al., 1995; O'Donnell et al., 1982b; Prauser et al., 1997; Rainey et al., 1993; Schumann et al., 1997; Tamura et al., 1994; Williams et al., 1989). Although K. aurantiaca is similar to the isolate in terms of menaquinone types and amino acids in the peptide subunit of the peptidoglycan, as well as in terms of phospholipid composition, it differs from the isolate in having meso-

Table 2. Differential characteristics of strain LM $161^{\top}$ and related taxa that belong to the suborder Propionibacterineae

Abbreviations: L-Ala, L-alanine; Gly, glycine; DPG, diphosphatidylglycerol; PC, phosphatidylcholine; PG, phosphatidylglycerol; PI, phosphatidylinositol; PG-OH, phosphatidylglycerol containing 2-hydroxy fatty acids; PL, unknown phospholipid(s); GL, unknown glycolipid(s).

\begin{tabular}{|c|c|c|c|c|c|c|}
\hline Taxon* & Morphology & $\begin{array}{l}\text { Amino acid at } \\
\text { position } 1 \text { of } \\
\text { peptide subunits }\end{array}$ & $\begin{array}{c}\text { Major } \\
\text { menaquinone } \dagger\end{array}$ & Polar lipids & Predominant fatty acids* & $\begin{array}{c}G+C \\
\text { content } \\
(\operatorname{mol} \%)\end{array}$ \\
\hline Strain LM $161^{\mathrm{T}}$ & Hyphae & L-Ala & MK-9 $\left(\mathrm{H}_{4}\right)$ & DPG, PC, PG, PI & ai- $C_{15: 0}, i-C_{16: 0}$ & $71 \cdot 3$ \\
\hline Nocardioides & Hyphae/rods & L-Ala & $\mathrm{MK}-8\left(\mathrm{H}_{4}\right)$ & DPG, PG, PG-OH, PL & $\mathrm{i}-\mathrm{C}_{16: 0}, \mathrm{C}_{18: 1}, \mathrm{TSBA}$ & $66 \cdot 4-72 \cdot 7$ \\
\hline Aeromicrobium & Rods & L-Ala & MK-9 $\left(\mathrm{H}_{4}\right)$ & PG, PE & $\mathrm{C}_{16: 0}, \mathrm{C}_{18: 1}, \mathrm{TSBA}$ & $71-73$ \\
\hline Propioniferax & Rods & L-Ala & MK-9 $\left(\mathrm{H}_{4}\right)$ & GL, PE, PG, PL & ai- $C_{15: 0}, \mathrm{i}-\mathrm{C}_{15: 0}$ & $59-63$ \\
\hline Friedmanniella & Cocci & Gly & MK-9 $\left(\mathrm{H}_{4}\right)$ & DPG, PG, PI, PL & ai- $C_{15: 0}, \mathrm{i}-\mathrm{C}_{15: 0}$ & 73 \\
\hline Luteococcus & Cocci & L-Ala & MK-9 $\left(\mathrm{H}_{4}\right)$ & DPG, GL, PG, PI, & $\mathrm{C}_{16: 1}, \mathrm{C}_{17: 1}, \mathrm{C}_{18: 1}$ & $66-68$ \\
\hline Microlunatus & Cocci & Gly & MK-9 $\left(\mathrm{H}_{4}\right)$ & DPG, PG, PI, PL & ai- $C_{15: 0}, \mathrm{i}-\mathrm{C}_{15: 0}, \mathrm{i}-\mathrm{C}_{16: 0}$ & $67 \cdot 9$ \\
\hline
\end{tabular}

* Data from Collins et al. (1989, 1994), Lechevalier (1989), Miller et al. (1991), Nakamura et al. (1995), O’Donnell et al. (1982a), Schumann et al. (1997), Tamura \& Yokota (1994), Tamura et al. (1994) and Yokota et al. (1994).

$\dagger$ The abbreviations for menaquinones and fatty acids are illustrated by the following examples: $\mathrm{MK}-9\left(\mathrm{H}_{4}\right)=$ menaquinone with two out of nine isoprene units hydrogenated; ai- $\mathrm{C}_{15: 0}, 12$-methyltetradecanoic acid; $\mathrm{i}_{-} \mathrm{C}_{16: 0}$, 14-methylpentadecanoic acid; TSBA, tuberculostearic acid (10-methyloctadecanoic acid); $\mathrm{C}_{16: 1}$, hexadecenoic acid. 
DAP as an additional diamino acid in the peptidoglycan, in having no iso/anteiso branched fatty acid profiles, in cell morphology and in having spore motility (Itoh et al., 1989). Phylogenetically, $K$. aurantica clusters with the members of the family Sporichthyaceae Rainey et al., 1997 of the suborder Frankineae Stackebrandt et al. (Stackebrandt et al., 1997) (Fig. 3). The chemotaxonomic characteristics of $K$. aurantiaca were also confirmed in our study (data not shown).

The other high $\mathrm{G}+\mathrm{C}$ DNA bacteria that have been described as having the phospholipid type III pattern are mainly nocardioform (rarely spore-forming actinomycetes) and contain the genera Actinopolyspora (Lechevalier, 1989), Faenia (Lechevalier, 1989), Nocardiopsis (Mayer, 1989), Saccharopolyspora (Lechevalier, 1989), Pseudonocardia (Lechevalier, 1989) and Catenuloplanes (Yokota et al., 1993). However, the isolated strain differs from these genera in terms of the diagnostic diamino acid and sugars in the peptidoglycan.

The phylogenetic analysis of 16S rDNA sequence comparisons reveals that the closest (albeit distant) phylogenetic relatives of the isolated strain are members of the families Nocardioidaceae and Propionibacteriaceae (Fig. 3). Among them, the genera Aeromicrobium (Miller et al., 1991; Tamura \& Yokota, 1994), Luteococcus (Tamura et al., 1994) and Propioniferax (Yokota et al., 1994) share, with the isloated strain, the following chemotaxonomic properties: the amino acids of the peptide subunit of the peptidoglycan, the occurrence of glycine in the interpeptide bridge and the menaquinone type $\mathrm{MK}-9\left(\mathrm{H}_{4}\right)$. However, these genera differ from the isolated strain in terms of the $\mathrm{G}+\mathrm{C}$ content of the DNA, in the composition of fatty acids and phospholipids and in the cell morphology (Table 2). Morphologically, two species of the genus Nocardioides, Nocardioides albus (Prauser, 1976) and Nocardioides luteus (Prauser, 1984), resemble the isolate in that all of these organisms produce well-developed, fragmented mycelium, but the genus Nocardioides is differentiated from our strain in possessing menaquinone type $\mathrm{MK}-8\left(\mathrm{H}_{4}\right)$, in lacking the diagnostic phospholipid phosphatidylcholine and by the fatty acid profiles (Tables 1 and 2).

Thus, phylogenetic evidence based on 16S rDNA sequence comparisons and chemotaxonomic properties indicate that the isolate can be readily distinguished from the previously described genera of the order Actinomycetales. Therefore, the new genus Hongia is proposed to accommodate the new isolate. Hongia koreensis is the type species. The type strain is strain LM $161^{\mathrm{T}}$.

\section{Description of Hongia gen. nov.}

Hongia [Hong'i.a. M.L. fem. n. Hongia named after Soon-Woo Hong (1927-1988), a Korean microbiologist who devoted his life to the study of soil micro-organisms].
The aerial mycelium is white and fragments into rodshaped elements. The substrate mycelium is creamy and fragments into short or elongated rod-shaped elements. The substrate hyphal swellings and budding are formed on oatmeal agar. Aerobic. Gram-positive. Not acid-fast. Oxidase-negative. Catalase- and ureasepositive. Chemo-organotrophic. Non-motile. Grows at $10-37^{\circ} \mathrm{C}$. Does not grow at $45^{\circ} \mathrm{C}$. The cell wall peptidoglycan contains LL-diaminopimelic acid, alanine, glycine and glutamic acid (approx. 1:2:1:1). The acyl type is acetyl. Mannose, glucose, galactose and ribose are present as cell wall sugars. The polar lipids are phosphatidylcholine, diphosphatidylglycerol, phosphatidylglycerol and phosphatidylinositol. The major menaquinone is MK-9 $\left(\mathrm{H}_{4}\right)$. The predominant fatty acids are 12-methyltetradecanoic acid and 14-methylpentadecanoic acid. Straight-chain saturated and 10-methyl fatty acids occur in small amounts. Mycolic acids are absent. The $\mathrm{G}+\mathrm{C}$ content of the DNA is $71.3 \mathrm{~mol} \%$. Phylogenetically, this genus branches at the root of members of the suborder Propionibacterineae. All signature nucleotides defined for the suborder Propionibacterineae are also found in strain LM $161^{\mathrm{T}}$, except for base-pair positions 671-735, at which strain LM $161^{\mathrm{T}}$ has a G-C pair rather than an $\mathrm{A}-\mathrm{U}$ pair. The type species is Hongia koreensis.

\section{Description of Hongia koreensis sp. nov.}

Hongia koreensis (ko.re.en'sis. M.L. adj. koreensis pertaining to Korea, the location of the soil sample from which the organism was isolated).

The aerial mycelium is white and fragments into rodshaped elements. The substrate mycelium is creamy and fragments into short or elongated rod-shaped elements. The substrate hyphal swellings and budding are formed on oatmeal agar. Nitrate is not reduced to nitrite. $\mathrm{H}_{2} \mathrm{~S}$ is produced. Utilizes D-arabinose, Larabinose, D-cellobiose, D-fructose, D-galactose, inulin, D-lactose, D-lyxose, D-mannose, D-melezitose, melibiose, methyl $\alpha$-D-glucoside, methyl $\alpha$-Dmannoside, D-raffinose, L-rhamnose, sucrose, D-trehalose, D-xylose, adonitol, D-mannitol, sodium acetate, trans-aconitate, sodium citrate, sodium fumarate, $\alpha$-ketoglutarate, sodium lactate, sodium malate, sodium malonate, sodium oxalate, sodium propionate, sodium pyruvate and sodium succinate as carbon sources. Gelatin, casein, starch, arbutin and aesculin are hydrolysed. Pectin and DNA are not hydrolysed. Xanthine, hypoxanthine, DL-tyrosine and sodium hippurate are decomposed but adenine is not decomposed. Acid is produced from D-raffinose. No acid is produced from D-arabinose, L-arabinose, D-cellobiose, D-fructose, D-galactose, D-glucose, inulin, D-lactose, maltose, D-mannose, D-melezitose, melibiose, methyl $\alpha$-D-glucoside, methyl $\alpha$-D-mannoside, L-rhamnose, Lribose, salicin, sucrose, D-trehalose, D-xylose, adonitol, 2, 3-butanediol, meso-erythritol, glycerol, meso-inositol, D-mannitol or 1, 2-propanediol. Tolerant to lysozyme, $0 \cdot 1 \%$ phenol, $0.01 \%$ potassium tellurite, 
$0.00005 \%$ crystal violet and $0.001 \%$ brilliant green, but not to $3 \%(\mathrm{w} / \mathrm{v})$ sodium chloride, $0.01 \%$ sodium azide, $0.3 \%$ phenylethanol or $0.01 \%$ thallous acetate. Susceptible to $40 \mathrm{~g}$ cephaloridine $\mathrm{ml}^{-1}$ and $20 \mathrm{~g}$ neomycin $\mathrm{ml}^{-1}$, but resistant to $4 \mathrm{~g}$ tetracycline $\mathrm{ml}^{-1}, 4 \mathrm{~g}$ rifampin $\mathrm{ml}^{-1}, 20 \mathrm{~g}$ streptomycin $\mathrm{ml}^{-1}, 160 \mathrm{~g}$ oleandomycin $\mathrm{ml}^{-1}$ and $4 \mathrm{~g}$ vancomycin $\mathrm{ml}^{-1}$. The cell wall peptidoglycan contains LL-diaminopimelic acid, alanine, glycine and glutamic acid (approx. $1: 2: 1: 1$ ). The acyl type is acetyl. Mannose, glucose, galactose and ribose are present as cell wall sugars. The diagnostic polar lipid is phosphatidylcholine. The major menaquinone is MK-9 $\left(\mathrm{H}_{4}\right)$. The predominant fatty acids are 12-methyltetradecanoic acid and 14-methylpentadecanoic acid. Mycolic acids are absent. The $\mathrm{G}+\mathrm{C}$ content of the DNA of the type strain is $71.3 \mathrm{~mol} \%$. The type strain of Hongia koreensis is strain LM $161^{\mathrm{T}}$ $\left(=\mathrm{IMSNU} 50530^{\mathrm{T}}\right)$. The only known isolation site is a gold-mine cave in Kongju, Republic of Korea.

\section{ACKNOWLEDGEMENTS}

We thank Dr Jung-Hye Roe and Dr Jae-Heon Kim for their encouragement and support. We are indebted to Professor Michael Goodfellow and Dr Peter Schumann for helpful discussions. We also wish to thank Min Young Kim for her technical assistance, and Dr Jong-Sik Chun for correcting this paper. This work was supported by a research grant to the Research Centre for Molecular Microbiology, Seoul National University from the Korea Science and Engineering Foundation (KOSEF).

\section{REFERENCES}

Brosius, J., Palmer, J. L., Kennedy, J. P. \& Noller, H. F. (1978). Complete nucleotide sequence of a $16 \mathrm{~S}$ ribosomal RNA gene from Escherichia coli. Proc Natl Acad Sci USA 75, 4801-4805.

Collins, M. D., Goodfellow, M. \& Minnikin, D. E. M. (1982). Polar lipid composition in the classification of Arthrobacter and Microbacterium. FEMS Microbiol Lett 15, 299-302.

Collins, M. D., Dorsch, M. \& Stackebrandt, E. (1989). Transfer of Pimelobacter tumescens to Terrabacter gen. nov. as Terrabacter tumescens comb. nov. and of Pimelobacter jensenii to Nocardioides as Nocardioides jensenii comb. nov. Int J Syst Bacteriol 39, 1-6.

Collins, M. D., Cockcroft, S. \& Wallbanks, S. (1994). Phylogenetic analysis of a new LL-diaminopimelic acid-containing coryneform bacterium from herbage, Nocardioides plantarum sp. nov. Int J Syst Bacteriol 44, 523-526.

Cummins, C. S. \& Johnson, J. L. (1986). Genus I. Propionibacterium Orla-Jensen 1909, 337 ${ }^{\mathrm{AL}}$. In Bergey's Manual of Systematic Bacteriology, vol. 2, pp. 1346-1353. Edited by P. H. A. Sneath, N. S. Mair, M. E. Sharpe \& J. G. Holt. Baltimore: Williams \& Wilkins.

Felsenstein, J. (1985). Confidence limits on phylogenies: an approach using the bootstrap. Evolution 39, 783-791.

Felsenstein, J. (1993). PHYLIP (phylogeny inference package), version 3.5c. Department of Genetics, University of Washington, Seattle.

Gordon, R. E., Barnett, D. A., Handerhan, J. E. \& Pang, C. H.-N. (1974). Nocardia coeliaca, Nocardia autotrophica, and the nocardia strain. Int J Syst Bacteriol 24, 54-63.
Hankin, L., Zucker, M. \& Sands, D. C. (1971). Improved solid medium for detection and enumeration of pectolytic bacteria. Appl Microbiol 22, 205-209.

Hopwood, D. A., Bibb, M. J., Chater, K. F. \& 7 other authors (1985). Genetic Manipulation of Streptomyces: a Laboratory Manual, Norwich: The John Innes Foundation.

Itoh, T., Kudo, T., Parenti, F. \& Seino, A. (1989). Amended description of the genus Kineosporia, based on chemotaxonomic and morphological studies. Int J Syst Bacteriol 39, 168-173.

Jukes, T. H. \& Cantor, C. R. (1969). Evolution of protein molecules. In Mammalian Protein Metabolism, pp. 21-132. Edited by H. N. Munro. New York: Academic Press.

Kalakoutskii, L. V., Kirillova, I. P. \& Krassilnikov, N. A. (1967). A new genus of the Actinomycetales, Intrasporangium gen. nov. $J$ Gen Microbiol 48, 79-85.

Kroppenstedt, R. M. (1985). Fatty acid and menaquinone analysis of actinomycetes and related organisms. In Chemical Methods in Bacterial Systematics, pp. 173-199. Edited by M. Goodfellow \& D. E. Minnikin. London: Academic Press.

Lechevalier, H. A. (1989). Section 26. Nocardioform actinomycetes. In Bergey's Manual of Systematic Bacteriology, vol. 4, pp. 2348-2404. Edited by S. T. Williams, M. E. Sharpe \& J. G. Holt. Baltimore: Williams \& Wilkins.

Lechevalier, M. P. \& Lechevalier, H. A. (1970). Chemical composition as a criterion in the classification of aerobic actinomycetes. Int J Syst Bacteriol 20, 435-443.

Lechevalier, M. P., Stern, A. E. \& Lechevalier, H. A. (1981). Phospholipids in the taxonomy of actinomycetes. Zentbl Bakteriol Hyg 1 Abt Suppl 11, 111-116.

Lee, S. D. (1996). Classification of novel actinomycetes from gold mine cave in Kongju, Korea. PhD thesis, Seoul National University.

Mac Faddin, J. F. (1980). Biochemical Tests for Identification of Medical Bacteria, 2nd edn. Baltimore: Williams \& Wilkins.

Marmur, J. \& Doty, P. (1962). Determination of the base composition of deoxyribonucleic acid from its thermal denaturation temperature. J Mol Biol 5, 109-118.

Mayer, J. (1989). Genus Nocardiopsis Mayer 1976, 487 ${ }^{\mathrm{AL}}$. In Bergey's Manual of Systematic Bacteriology, vol. 4, pp. 2562-2568. Edited by S. T. Williams, M. E. Sharpe \& J. G. Holt. Baltimore: Williams \& Wilkins.

Miller, E. S., Woese, C. R. \& Brenner, S. (1991). Description of the erythromycin-producing bacterium Arthrobacter sp. strain NRRL B-3381 as Aeromicrobium erythreum gen. nov., sp. nov. Int $J$ Syst Bacteriol 41, 363-368.

Minnikin, D. E. M. (1988). Isolation and purification of mycobacterial wall lipids. In Bacterial Cell Surface Techniques, pp. 125-135. Edited by I. C. Hancock \& I. R. Poxton. Chichester: Wiley.

Minnikin, D. E., Patel, P. V., Alshamaony, L. \& Goodfellow, M. (1977). Polar lipid composition in the classification of Nocardia and related bacteria. Int J Syst Bacteriol 27, 104-117.

Minnikin, D. E., Hutchinson, I. G., Caldicott, A. B. \& Goodfellow, M. (1980). Thin layer chromatography of methanolysates of mycolic acid-containing bacteria. J Chromatogr 188, 221-233.

Minnikin, D. E., O’Donnell, A. G., Goodfellow, M., Alderson, G., Athalye, M., Schaal, A. \& Parlett, J. H. (1984). An integrated procedure for the extraction of bacterial isoprenoid quinones and polar lipids. J Microbiol Methods 2, 233-241.

Nakamura, K., Hiraishi, A., Yoshimi, Y., Kawaharasaki, M., Masuda, K. \& Kamagata, Y. (1995). Microlunatus phosphovorus 
gen. nov., sp. nov., a new gram-positive polyphosphateaccumulating bacterium isolated from activated sluge. Int $J$ Syst Bacteriol 45, 17-22.

O’Donnell, A. G., Goodfellow, M. \& Minnikin, D. E. (1982a). Lipids in the classification of Nocardioides: reclassification of Arthrobacter simplex (Jensen) Lochhead in the genus Nocardioides (Prauser) emend. O'Donnell et al. as Nocardioides simplex comb. nov. Arch Microbiol 133, 323-329.

O'Donnell, A. G., Minnikin, D. E., Goodfellow, M. \& Parlett, J. H. (1982b). The analysis of actinomyces wall amino acids by gas chromatography. FEMS Microbiol Lett 15, 75-78.

Pitcher, D. G. \& Collins, M. D. (1991). Phylogenetic analysis of some LL-diaminopimelic acid-containing coryneform bacteria from human skin: description of Propionibacterium innocuum sp. nov. FEMS Microbiol Lett 84, 295-300.

Prauser, H. (1976). Nocardioides, a new genus of the order Actinomycetales. Int J Syst Bacteriol 26, 58-65.

Prauser, H. (1984). Nocardioides luteus spec. nov. $Z$ Allg Mikrobiol 24, 647-648.

Prauser, H., Schumann, P., Rainey, F. A., Kroppenstedt, R. M. \& Stackebrandt, E. (1997). Terracoccus luteus gen. nov., sp. nov., an LL-diaminopimelic acid-containing coccoid actinomycete from soil. Int J Syst Bacteriol 47, 1218-1224.

Pridham, T. G. \& Gottlieb, D. (1948). The utilization of carbon compounds by some Actinomycetales as an aid for species determination. J Bacteriol 56, 107-114.

Rainey, F. A., Schumann, P., Prauser, H., Toalster, R. \& Stackebrandt, E. (1993). Sporichthya polymorpha represents a novel line of descent within the order Actinomycetales. FEMS Microbiol Lett 109, 263-268.

Saddler, G. S., Tavecchia, P., Lociuro, S., Zanol, M., Colombo, E. \& Selva, E. (1991). Analysis of madurose and other actinomycete whole cell sugars by gas chromatography. J Microbiol Methods 14, 185-191.

Saitou, N. \& Nei, M. (1987). The neighbor-joining method: a new method for reconstructing phylogenetic trees. Mol Biol Evol 4, 406-425.

Schleifer, K. H. \& Kandler, O. (1972). Peptidoglycan types of bacterial cell walls and their chemotaxonomic implications. Bacteriol Rev 36, 407-477.

Schumann, P., Prauser, H., Rainey, F. A., Stackebrandt, E. \& Hirsch, P. (1997). Friedmanniella antarctica gen. nov., sp. nov., an LL-diaminopimelic acid-containing actinomycete from antarctic sandstone. Int J Syst Bacteriol 47, 278-283.

Shirling, E. B. \& Gottlieb, D. (1966). Methods for characterization of Streptomyces species. Int J Syst Bacteriol 16, 313-340.

Stackebrandt, E., Rainey, F. A. \& Ward-Rainey, N. L. (1997).
Proposal for a new hierarchic classification system, Actinobacteria class. nov. Int J Syst Bacteriol 47, 479-491.

Staneck, J. L. \& Roberts, G. D. (1974). Simplified approach to identification of aerobic actinomycetes by thin-layer chromatography. Appl Microbiol 28, 226-231.

Tamura, T. \& Yokota, A. (1994). Transfer of Nocardioides fastidiosa Collins and Stackebrandt 1989 to the genus Aeromicrobium as Aeromicrobium fastidiosum comb. nov. Int J Syst Bacteriol 44, 608-611.

Tamura, T., Takeuchi, M. \& Yokota, A. (1994). Luteococcus japonicus gen. nov., sp. nov., a new gram-positive coccus with LL-diaminopimelic acid in the cell wall. Int $J$ Syst Bacteriol 44, 348-356.

Thompson, J. D., Higgins, D. G. \& Gibson, T. J. (1994). CLUSTAL $\mathrm{W}$ : improving the sensitivity of progressive multiple sequence alignment through sequence weighing, position-specific gap penalties and weight matrix choice. Nucleic Acids Res 22, 4673-4680.

Uchida, K. \& Aida, K. (1984). An improved method for the glycolate test for simple identification of the acyl type of bacterial cell walls. J Gen Appl Microbiol 30, 131-134.

Waksman, S. A. (1961). Classification, identification, and description of genera and species. In The Actinomycetes, vol. 2, pp. 1-363. Baltimore: Williams \& Wilkins.

Williams, S. T., Goodfellow, M., Alderson, E., Wellington, E. M. H., Sneath, P. H. A. \& Sackin, M. (1983). Numerical classification of Streptomyces and related genera. J Gen Microbiol 129, 1743-1813.

Williams, S. T., Goodfellow, M. \& Alderson, E. (1989). Genus Streptomyces Waksman and Henrici 1943, 339 ${ }^{\mathrm{AL}}$. In Bergey's Manual of Systematic Bacteriology, vol. 4, pp. 2452-2492. Edited by S. T. Williams, M. E. Sharpe \& J. G. Holt. Baltimore: Williams \& Wilkins.

Yamada, K. \& Komagata, K. (1972). Taxonomic studies on coryneform bacteria. V. Classification of coryneform bacteria. $J$ Gen Appl Microbiol 18, 417-431.

Yokota, A., Tamura, T., Hasegawa, T. \& Huang, L. H. (1993). Catenuloplanes japonicus gen. nov., sp. nov., nom. rev., a new genus of the order Actinomycetales. Int J Syst Bacteriol 43, 805-812.

Yokota, A., Tamura, T., Takeuchi, M., Weiss, N. \& Stackebrandt, E. (1994). Transfer of Propionibacterium innocuum Pitcher \& Collins 1991 to Propioniferax gen. nov. as Propioniferax innocua comb. nov. Int J Syst Bacteriol 44, 579-582.

Yoon, J.-H., Lee, S. T. \& Park, Y.-H. (1998). Inter- and intraspecific phylogenetic analysis of the genus Nocardioides and related taxa based on 16S rDNA sequences. Int J Syst Bacteriol 48, 187-194. 